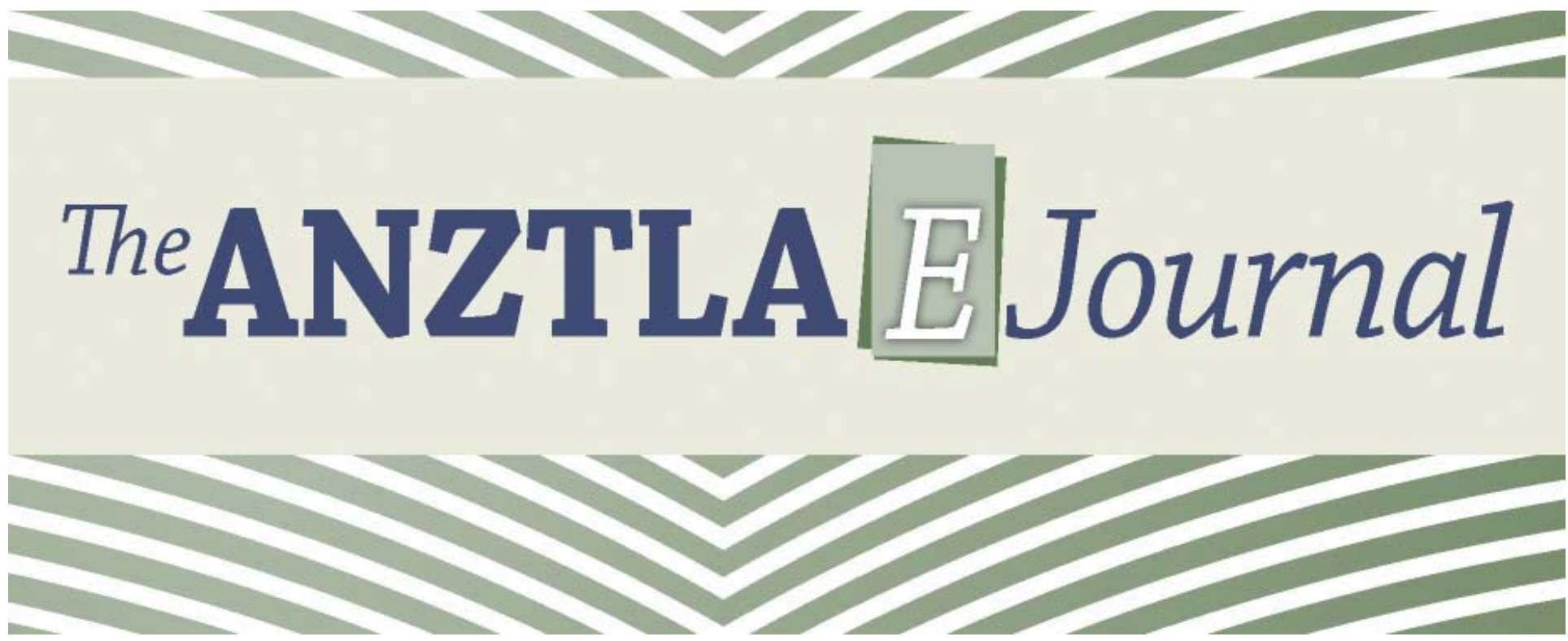

Australian and New Zealand Theological Library Association W W No. 2 (2009)

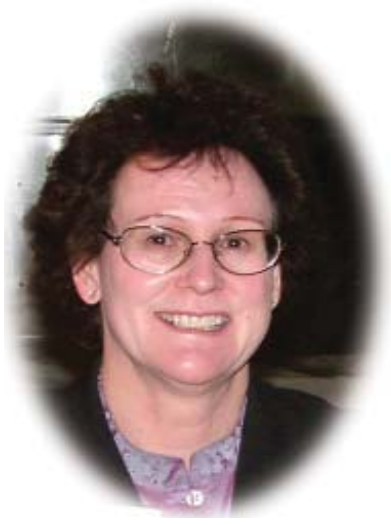

\section{Helen Brennan}

Journal Manager

St Ann's Library, Vianney College

Wagga Wagga NSW
$T$ elcome to the second issue of The ANZTLA EJournal the official serial publication of the Australian and New Zealand Theological Library Association. Published twice a year, one issue covers presentations from the annual conference, while the other includes submissions from throughout the year. Further information, including Author Guidelines, can be found at the journal website, www.nla.gov.au/openpublish/index. php/ANZTLA. The ISSN for The ANZTLA EJournal is 1839-8758.

This issue presents two papers by the late Abbot of New Norcia, Placid Spearrit and a report from Nalini Premadish after her attendance at the 2008 Wellington Conference. Hilary Regan's reflection on Where Theology Meets the World was delivered at the 2008 ACD graduation. Lastly Kerrie Stevens, the ANZTLA statistician, presents the 2007 and 2008 information relating to our member libraries.

Enjoy!

\section{Eve James}

\title{
Contents
}

2 Monk as Reluctant Cataloguer

8 Confessions of a Bibliophile

Monk

13 Jeanette Little Scholarship Recipient Report
15 Where Theology Meets the World

222007 Statistics Report

362008 Statistics Report 